\title{
The Influence Of Islamic Income And Financial Literacy On The Decision To Finance In Islamic Banks
}

\author{
Saparuddin ${ }^{1}$, Windari ${ }^{2}$, Azwar Hamid, Ananda ${ }^{4}$ \\ ${ }^{1}$ IAIN Padangsidimpuan (Perbankan Syariah, FEBI, IAIN Padangsidimpuan) \\ ${ }^{2}$ IAIN Padangsidimpuan (Ekonomi Syariah, FEBI, IAIN Padangsidimpuan) \\ ${ }^{3}$ IAIN Padangsidimpuan (Perbankan Syariah, FEBI, IAIN Padangsidimpuan) \\ ${ }^{4}$ IAIN Padangsidimpuan (Ekonomi Syariah, FEBI, IAIN Padangsidimpuan) \\ saparuddin@gmail.com ${ }^{1}$, wwindariok@gmail.com ${ }^{2}$ ' azwarhamid@iain-padangsidimpuan.ac.id $^{3}$ \\ anandaanugrah@iain-padangsidimpuan.ac.id ${ }^{4}$
}

\begin{abstract}
ABSTRAK
Hasil survei awal pedagang di Kecamatan Panyabungan sebanyak 37 dari 50 memilih kredit dari bank konvensional dibandingkan pembiayaan di bank syariah. Penurunan tingkat pendapatan masyarakat secara drastis akibat penyakit virus corona, mengakibatkan menurunnya daya beli masyarakat sehingga akan mempengaruhi pendapatan para pedagang. Rendahnya literasi keuangan syariah yang terjadi pada masyarakat, dimana hanya sebesar $8,93 \%$ jauh di bawah literasi keuangan nasional sebesar $38,03 \%$. Rumusan masalah dalam penelitian ini adalah apakah pendapatan berpengaruh terhadap keputusan pedagang melakukan pembiayaan di bank syariah di Kecamatan Panyabungan? apakah literasi keuangan syariah berpengaruh terhadap keputusan pedagang melakukan pembiayaan di bank syariah di Kecamatan Panyabungan? apakah pendapatan dan literasi keuangan syariah secara simultan berpengaruh terhadap keputusan pedagang melakukan pembiayaan di bank syariah di Kecamatan Panyabungan?. Penelitian ini adalah penelitian kuantitatif. Sampel dalam penelitian ini berjumlah 70 responden dengan menggunakan teknik sampling insidental. Teknik analisis data yang digunakan adalah uji validitas, uji reliabilitas, uji analisis statistik deskriptif, uji normalitas, uji multikolinearitas, uji heterokedastisitas, uji regresi linear berganda, uji t, dan uji $F$. Hasil penelitian menggunakan uji t pendapatan dengan $-t_{\text {tabel }} \leq t_{\text {hitung }} \leq t_{\text {tabel }}(-1,66792 \leq-$ $1,304 \leq 1,66792$ ) dengan sig. 0,197 >0,1, dapat disimpulkan bahwa pendapatan tidak berpengaruh terhadap keputusan pedagang melakukan pembiayaan di bank syariah di Kecamatan Panyabungan, literasi keuangan syariah dengan $t_{\text {hitung }}>t_{\text {tabel }}(3,646>1,66792)$ dengan sign. $0,001<0,1$, dapat disimpulkan bahwa literasi keuangan syariah berpengaruh terhadap keputusan pedagang melakukan pembiayaan di bank syariah di Kecamatan Panyabungan. Hasil uji $F$ menunjukkan $F_{\text {hitung }}$ sebesar 7,232 $>F_{\text {tabel }}$ sebesar 2,38 dengan sign. 0,001 $<0,1$, sehingga disimpulkan bahwa pendapatan dan literasi keuangan syariah secara simultan berpengaruh terhadap keputusan pedagang melakukan pembiayaan di bank syariah di Kecamatan Panyabungan.
\end{abstract}

Kata Kunci: Pengetahuan, Minat

\section{ABSTRACT}

The results of the initial survey of traders in Panyabungan District as many as 37 out of 50 chose credit from conventional banks over financing in Islamic banks. The decrease in people's income levels drastically due to coronavirus disease, resulting in lowering people's purchasing power so that it will affect the income of traders. The low Islamic financial literacy that occurs in the community, which is only $8.93 \%$, is far below the national financial literacy of $38.03 \%$. The formulation of the problem in this study is whether income has an effect on traders' decisions to finance at Islamic banks in Panyabungan District? Does Islamic financial literacy affect traders' decisions to finance at Islamic banks in Panyabungan District? Do income and Islamic financial 
literacy simultaneously affect the decision of traders to do financing at Islamic banks in Panyabungan District?. This research is quantitative research. The sample in this study amounted to 70 respondents using the incidental sampling technique. The data analysis techniques used are validity test, reliability test, descriptive statistical analysis test, normality test, multicollinearity test, heteroscedasticity test, multiple linear regression test, $\mathrm{t}$-test, and $\mathrm{F}$ test. The results of the study used the $t$-test of income with $-t_{\text {table }} \leqslant t_{\text {count }} \leqslant t_{\text {table }}(-1.66792 \leqslant-1.304 \leqslant 1.66792)$ with sig. $0.197>$ 0.1 , it can be concluded that income has no effect on the decision of traders to finance at Islamic banks in Panyabungan District, Islamic financial literacy with $t_{\text {count }}>t_{\text {table }}(3.646>1.66792)$ with a sign. $0.001<0.1$, it can be concluded that Islamic financial literacy affects the decision of traders to finance at Islamic banks in Panyabungan District. The results of the $F$ test show that $F_{\text {count }}$ is $7.232>$ $F_{\text {table }}$ is 2.38 with a sign. $0.001<0.1$, so it can be concluded that income and Islamic financial literacy simultaneously affect the decision of traders to finance at Islamic banks in Panyabungan District.

Keywords: Knowledge, Interest

\section{A. PENDAhuluan}

Salah satu produk dari bank syariah adalah pembiayaan. Pembiayaan adalah salah satu dari produk bank syariah yang ditujukan untuk membantu masyarakat dalam pengembangan usaha dalam rangka meningkatkan kesejahteraan masyarakat. Menurut Undang-Undang Republik Indonesia No. 21 Tahun 2008 bahwa pembiayaan adalah penyediaan dana atau tagihan yang dipersamakan dengan itu berupa transaksi bagi hasil, transaksi sewa menyewa, jual beli, pinjam meminjam dan sewa menyewa dalam bentuk multijasa. Sebagai upaya dalam rangka meningkatkan pertumbuhan ekonomi, salah satunya dengan memberdayakan UMKM. Kehadiran pembiayaan khususnya pembiayaan dari bank syariah sangat diperlukan bagi pedagang baik itu pedagang kecil maupun pedagang besar.

Menurut data Survei Nasional Literasi dan Inklusi Keuangan (SNLIK) ketiga yang dilakukan oleh Otoritas Jasa Keuangan (OJK) pada tahun 2019 menunjukkan bahwa indeks literasi keuangan sebesar 38,03\%, dan literasi keuangan syariah sebesar $8,93 \%$ serta indeks inklusi keuangan sebesar 76,19\%. Dengan demikian, data diatas menunjukkan bahwa masih rendahnya literasi keuangan syariah yang hanya sebesar $8,93 \%$ jauh dibawah literasi keuangan nasional sebesar 38,03\%. Data tersebut menunjukkan bahwa penduduk Indonesia yang merupakan mayoritas muslim belum sepenuhnya memahami literasi keuangan syariah tersebut. Dengan perbandingan yang cukup jauh dengan literasi keuangan nasional, diperlukan adanya sebuah pengedukasian kepada masyarakat akan pentingnya sebagai muslim untuk memahami literasi keuangan syariah terlebih penduduk Indonesia mayoritas adalah muslim.

Berdasarkan pada Kajian Fiskal Regional Provinsi Sumatera Utara berkurangnya aktivitas perekonomian menyebabkan 43,14\% mengalami penurunan pendapatan serta $55,57 \%$ pendapatan yang diterimanya tetap dan $1,3 \%$ mengalami peningkatan pendapatan. Berdasarkan pada kelompok pendapatan, 
masyarakat yang berpendapatan diatas 7,2 juta mengalami penurunan pendapatan sebesar $33,15 \%$, dan penurunan sebesar $35,99 \%$ bagi masyarakat berpendapatan antara 1,8 sampai 7,2 juta dan pendapatan dibawah 1,8 juta mengalami penurunan terbesar yaitu $70,22 \%$ (Kementerian Keuangan Direktorrat Jenderal Perbendaharaan Kantor Wilayah Provinsi Sumatera Utara 2020, 24-25).

\section{B. METODE}

Lokasi yang dijadikan sebagai tempat penelitian adalah Kecamatan Panyabungan. Adapun waktu penelitian ini dimulai dari bulan Agustus 2020 sampai April 2021. Jenis penelitian ini adalah penelitian kuantitatif. Penelitian kuantitatif adalah penelitian dengan menggunkan metode untuk menguji teori tertentu dengan meneliti hubungan antar variabel (Noor 2011, 38).

Populasi adalah wilayah generalisasi yang mana terdiri dari sekumpulan objek/subyek dengan ciri-ciri tertentu yang ditetapkan oleh peneliti (Sugiyono 2016, 80). Sampel adalah sebagian dari populasi yang memiliki jumlah dan karakteristik tertentu (Sugiyono 2016, 81) dan teknik sampling dalam penelitian ini adalah sampling incidental, dimana Sampling insidental adalah pengambilan sampel berdasarkan kebetulan, yaitu siapa saja yang secara tidak sengaja berjumpa dengan peneliti dan dianggap cocok dan sesuai dapat menjadi sampel.
POINT Vol. 2, No. 2, Des 2021

Jumlah populasi dalam penelitian ini tidak diketahui secara pasti, maka untuk menentukan jumlah sampel dari populasi tidak diketahui, peneliti menggunakan pendekatan Isac Michel (Siregar 2012, 149) dengan rumus sebagai berikut:

$$
\begin{aligned}
& n=\frac{\left(z_{\alpha / 2}\right)^{2} p \cdot q}{e^{2}} \\
& n=\frac{(1,64)^{2} 0,5.0,5}{(0,1)^{2}} \\
& n=67,24
\end{aligned}
$$

Jumlah sampel yang diperoleh adalah 67,24 maka dibulatkan menjadi 68 sampel. Jadi jumlah minimal sampel yang digunakan dalam penelitian ini berjumlah 68 sampel. Instrumen pengumpulan data yang digunakan adalah angket, dengan meyebarkan sejumlah rincian daftar pertanyaan kepada para responden.

Teknik analisis data yang digunakan adalah uji validitas, uji reliabilitas, uji analisis statistik deskriptif, uji normalitas, uji multikolinearitas, uji heterokedastisitas, uji regresi linear berganda, uji t, dan uji F.

\section{HASIL DAN PEMBAHASAN}

1. Hasil Analisis Deskriptif

Tabel 1

Hasil Analisis Deskriptif

\begin{tabular}{|l|l|c|c|c|c|}
\hline Variabel & $\mathrm{N}$ & $\begin{array}{c}\text { Mini } \\
\mathrm{mu} \\
\mathrm{m}\end{array}$ & $\begin{array}{c}\text { Maxi } \\
\text { mum }\end{array}$ & Mean & $\begin{array}{c}\text { Std. } \\
\text { Diviation } \\
\text { Statistic }\end{array}$ \\
\hline $\begin{array}{l}\text { Pendap } \\
\text { atan }\end{array}$ & 70 & 24 & 60 & 38.46 & 8.039 \\
\hline Literasi & 70 & 28 & 44 & 36 & 3.707 \\
\hline $\begin{array}{l}\text { Keputus } \\
\text { an }\end{array}$ & 70 & 33 & 55 & 42.56 & 4.366 \\
\hline
\end{tabular}

Sumber: Data Diolah 
Pada tabel 1 di atas, hasil uji statistik deskriptif untuk variabel independen, yaitu variabel pendapatan (dalam ratus ribu rupiah) memiliki nilai minimum Rp24 dan nilai maksimum Rp60, dan mean Rp38,46 dengan standar deviasi statistik sebesar Rp8,039. Kemudian variabel literasi keuangan syariah dengan nilai minimum 28 dan nilai maksimum 44, serta memiliki mean sebesar 36 dan standar diviasi statistik sebesar 3,707 . Sedangkan hasil uji statistik deskriptif untuk variabel dependen yaitu keputusan melakukan pembiayaan di bank syariah memiliki nilai minimum 33 dan nilai maksimum 55, serta memiliki mean sebesar 42,56 dan standar diviasi statistik sebesar 4,366 .

2. Hasil Uji Validitas

Tabel 2

Hasil Uji Validitas

\begin{tabular}{|c|c|c|c|c|}
\hline Variabel & $\begin{array}{c}\text { Pernyata } \\
\text { an }\end{array}$ & $r_{\text {hitung }}$ & $r_{\text {tabel }}$ & $\begin{array}{c}\text { Keteran } \\
\text { gan }\end{array}$ \\
\hline \multirow{9}{*}{$\begin{array}{c}\text { Literasi } \\
\text { Keuangan } \\
\text { Syariah }\end{array}$} & 1 & 0,634 & \multirow{9}{*}{$\begin{array}{c}0,198 \\
2\end{array}$} & Valid \\
\hline & 2 & 0,744 & & Valid \\
\hline & 3 & 0,576 & & Valid \\
\hline & 4 & 0,564 & & Valid \\
\hline & 5 & 0,677 & & Valid \\
\hline & 6 & 0,497 & & Valid \\
\hline & 7 & 0,601 & & Valid \\
\hline & 8 & 0,382 & & Valid \\
\hline & 9 & 0,530 & & Valid \\
\hline \multirow{8}{*}{$\begin{array}{c}\text { Keputusan } \\
\text { Melakukan } \\
\text { Pembiayaan } \\
\text { di Bank } \\
\text { Syariah }\end{array}$} & 1 & 0,663 & \multirow{8}{*}{$\begin{array}{c}0,198 \\
2\end{array}$} & Valid \\
\hline & 2 & 0,711 & & Valid \\
\hline & 3 & 0,627 & & Valid \\
\hline & 4 & 0,716 & & Valid \\
\hline & 5 & 0,807 & & Valid \\
\hline & 6 & 0,594 & & Valid \\
\hline & 7 & 0,507 & & Valid \\
\hline & 8 & 0,529 & & Valid \\
\hline
\end{tabular}

\begin{tabular}{|l|c|c|c|c|}
\hline & 9 & 0,363 & \multirow{4}{*}{} & Valid \\
\cline { 2 - 3 } & 10 & 0,453 & & Valid \\
\cline { 2 - 3 } & 11 & 0,458 & & Valid \\
\hline
\end{tabular}

Sumber: Data Diolah

Hasil uji validitas variabel literasi keuangan syariah pada tabel 2 , masing-masing item memiliki nilai rhitung yang lebih besar dibanding nilai $r_{\text {tabel. }}$. Oleh karena itu, dapat disimpulkan bahwa seluruh item pernyataan pada variabel literasi keuangan syariah adalah valid untuk digunakan sebagai alat ukur variabel.

Kemudian uji validitas variabel keputusan melakukan pembiayaan di bank syariah menunjukkan bahwa seluruh item pernyataan menghasilkan nilai rhitung yang lebih besar dibandingkan dengan nilai rtabel. Maka, seluruh item peryataan variabel keputusan melakukan pembiayaan di bank syariah tersebut adalah valid untuk digunakan sebagai alat ukur variabel.

\section{Hasil Uji Reliabilitas}

Tabel 3

Hasil Uji Reliabilitas Literasi Keuangan Syariah dan Keputusan Melakukan Pembiayaan di Bank Syariah

\begin{tabular}{|c|l|c|c|}
\hline No & \multicolumn{1}{|c|}{ Variabel } & $\begin{array}{c}\text { Cronbach's } \\
\text { Alpha }\end{array}$ & $\begin{array}{c}\mathrm{N} \text { of } \\
\text { Item }\end{array}$ \\
\hline 1 & $\begin{array}{l}\text { Literasi keuangan } \\
\text { syariah }\end{array}$ & .751 & 9 \\
\hline 2 & $\begin{array}{l}\text { Keputusan } \\
\text { melakukan } \\
\text { pembiayaan di } \\
\text { bank syariah }\end{array}$ & .813 & 11 \\
\hline
\end{tabular}

Sumber: Data Diolah

Hasil uji reliabilitas variabel literasi keuangan syariah pada tabel 3 menghasilkan nilai cronbach's alpha sebesar 0,751 >0,6 dan 
Saparuddin ${ }^{1}$, Windari ${ }^{2}$, Azwar Hamid ${ }^{3}$, Ananda Anugrah ${ }^{4}$

POINT Vol. 2, No. 2, Des 2021

variabel keputusan melakukan pembiayaan di bank syariah dengan nilai cronbach's alpha sebesar 0,813 >0,6. Maka dapat disimpulkan bahwa variabel literasi keuangan syariah dan keputusan melakukan pembiayaan di bank syariah dinyatakan reliable.

4. Hasil Uji Normalitas

Tabel 4

Hasil Uji Normalitas

Sumber: Data Diolah

Hasil uji normalitas pada tabel 4 , terlihat bahwa nilai asyimp. sign. (2-tailed) sebesar $0,200>0,1$. Maka dengan demikian, dapat disimpulkan bahwa data dalam penelitian ini berdistribusi normal.

1. Hasil Uji Multikolinearitas

Tabel 5

Hasil Uji Multikolinearitas

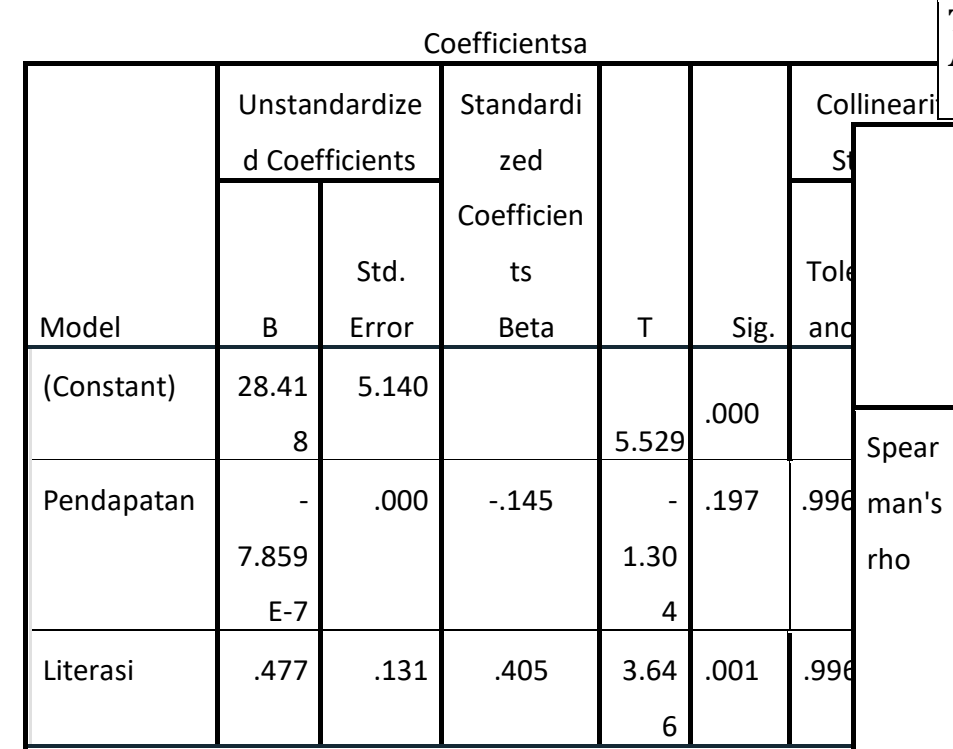

a. Dependent Variable: Keputusan

Sumber: Data Diolah

Hasil uji multikolinearitas pada tabel 5, variabel pendapatan memiliki nilai tolerance sebesar 0,996 > 0,1 dan nilai VIF sebesar 1,004 $<10$, variabel literasi keuangan syariah memiliki nilai tolerance sebesar 0,996 $>0,1$ dan nilai VIF sebesar $1,004<10$. Jadi dapat disimpulkan bahwa semua variabel independen diatas tidak terjadi multikolinearitas.

2. Hasil Uji Heteroskedastisitas

Tabel 6

Hasil Uji Heteroskedastisitas

Correlations

One-Sample Kolmogorov-Smirnov Test

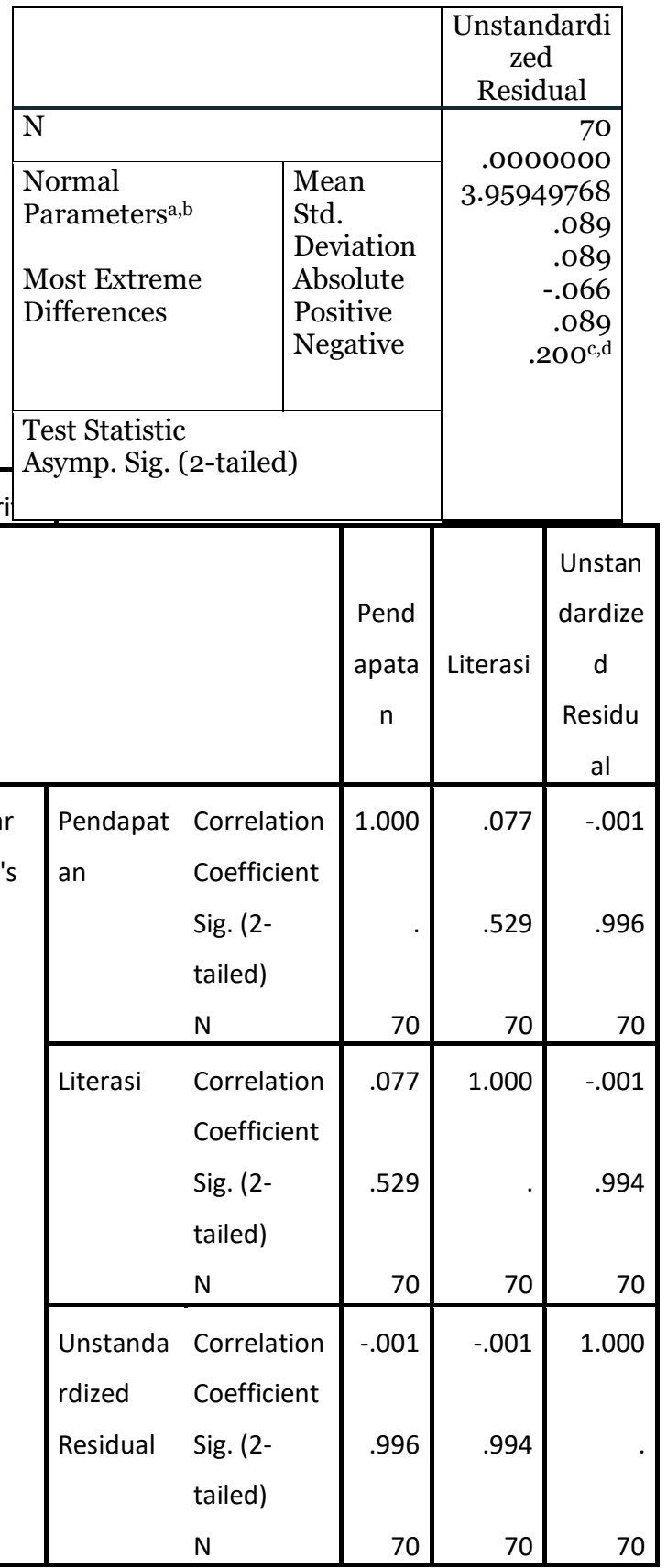


Sumber: Data Diolah

Hasil uji heteroskedastisitas pada tabel 6 menujukkan bahwa variabel pendapatan memiliki sig. (2-tailed) sebesar 0,996, dan variabel literasi keuangan syariah dengan sig. (2-tailed) sebesar 0,994. Hasil uji heteroskedastisitas diatas, kedua variabel memiliki nilai signifikansi > 0,1, maka tidak terdapat gejala heteroskedastisitas dalam penelitian ini.

\section{Hasil Uji Regresi Linear Berganda}

Tabel 7

Hasil Uji Regresi Linear Berganda Coefficientsa

\begin{tabular}{|c|c|c|c|c|c|}
\hline \multirow[b]{2}{*}{ Model } & \multicolumn{2}{|c|}{$\begin{array}{c}\text { Unstandardized } \\
\text { Coefficients }\end{array}$} & \multirow{2}{*}{$\begin{array}{c}\text { Standardi } \\
\text { zed } \\
\text { Coefficie } \\
\text { nts } \\
\text { Beta }\end{array}$} & \multirow[b]{2}{*}{$\mathrm{T}$} & \multirow[b]{2}{*}{ Sig. } \\
\hline & B & Std. Error & & & \\
\hline $\begin{array}{l}\text { (Constan } \\
\text { t) }\end{array}$ & $\begin{array}{r}28.41 \\
8 \\
\end{array}$ & 5.140 & & 5.529 & .000 \\
\hline $\begin{array}{l}\text { Pendapat } \\
\text { an }\end{array}$ & -.079 & .060 & -.145 & $\begin{array}{r}- \\
1.304\end{array}$ & .197 \\
\hline Literasi & .477 & .131 & .405 & 3.646 & .001 \\
\hline
\end{tabular}

Sumber: Data Diolah

Hasil dari uji regresi linear berganda pada tabel 7 diperoleh hasil regresi antara variabel pendapatan, literasi keuangan syariah terhadap keputusan melakukan pembiayaan di bank syariah, sehingga persamaan regresi linear berganda sebagai berikut:

$$
K=28,418-0.079 P+0,477 L+e
$$

Penjelasan dari persamaan diatas adalah:

a. Konstanta sebesar 28,418 artinya apabila pendapatan dan literasi keuangan syariah nilainya 0 , maka keputusan melakukan pembiayaan di bank syariah nilainya sebesar 28,418 .

b. Koefisien regresi pendapatan (dalam ratus ribu rupiah) bernilai negatif sebesar -0.079 rupiah, artinya apabila pendapatan meningkat sebesar Rp100.000, maka keputusan melakukan pembiayaan di bank syariah mengalami penurunan sebesar 0.079 rupiah. Tanda negatif menunjukkan hubungan negatif antara pendapatan terhadap keputusan melakukan pembiayaan di bank syariah.

c. Koefisien regresi literasi keuangan syariah memiliki nilai positif sebesar 0,477 satuan, artinya apabila literasi keuangan syariah mengalami kenaikan satu satuan, maka keputusan melakukan pembiayaan di bank syariah mengalami kenaikan sebesar 0,477 satuan. Tanda positif menunjukkan hubungan positif antara literasi keuangan syariah terhadap keputusan melakukan pembiayaan di bank syariah.

4. Hasil Uji t

Tabel 8

Hasil Uji t



Sumber: Data Diolah

Hasil uji t variabel pendapatan pada tabel 8 diperoleh nilai thitung sebesar $-1,304$ 
dengan tingkat signifikansi 0,197, dan variabel literasi keuangan syariah diperoleh thitung sebesar 3,646 dengan tingkat signifikansi 0,001. Nilai $t_{\text {tabel }}$ diperoleh dengan rumus $\mathrm{df}=\mathrm{n}-\mathrm{k}=$ $70-3=67$ dengan signifikansi 10\% $(0,1)$ diperoleh nilai ttabel sebesar 1,66792. Berdasarkan tabel diatas, maka variabel pendapatan dengan $-t_{\text {tabel }} \leq t_{\text {hitung }} \leq t_{\text {tabel }}($ $1,66792 \leq-1,304 \leq 1,66792)$ dengan sig. 0,197 $>0,1$, maka HO diterima dan hipotesis 1 ditolak. Jadi dapat disimpulkan bahwa pendapatan tidak berpengaruh terhadap keputusan pedagang melakukan pembiayaan di bank syariah di Kecamatan Panyabungan. Kemudian, variabel literasi keuangan syariah dengan $t_{\text {hitung }}>t_{\text {tabel }}(3,646>1,66792)$ dengan sign. 0,001<0,1, maka HO ditolak dan hipotesis 2 diterima. Jadi dapat disimpulkan bahwa literasi keuangan syariah berpengaruh terhadap keputusan pedagang melakukan pembiayaan di bank syariah di Kecamatan Panyabungan.

5. Hasil Uji F

Tabel 9

Hasil Uji F

POINT Vol. 2, No. 2, Des 2021 diperoleh $F_{\text {hitung }}$ sebesar 7,232 $>F_{\text {tabel }}$ sebesar 2,38 dengan sign. 0,001 $<0,1$, maka HO ditolak hipotesis 3 diterima. Jadi dapat disimpulkan bahwa pendapatan dan literasi keuangan syariah secara simultan berpengaruh terhadap keputusan pedagang melakukan pembiayaan di bank syariah di Kecamatan Panyabungan

\section{PENUTUP}

\section{Kesimpulan}

Penelitian ini sudah melewati tahap penyebaran angket kepada responden dan juga telah melewati uji statistik, sehingga hasil penelitian adalah sebagai berikut:

1. Pengaruh Pendapatan Terhadap Keputusan Melakukan Pembiayaan di Bank Syariah Hasil pengujian terlihat bahwa $-t_{\text {tabel }} \leq t_{\text {hitung }}$ $\leq t_{\text {tabel }} \quad(-1,66792 \leq-1,304 \leq 1,66792)$ dengan sig. 0,197 >0,1, maka HO diterima dan hipotesis 1 ditolak. Jadi dapat disimpulkan bahwa pendapatan tidak berpengaruh terhadap keputusan pedagang melakukan pembiayaan di bank syariah di Kecamatan Panyabungan.

\begin{tabular}{|l|l|r|r|r|r|l|}
\multicolumn{2}{|l|}{ Model } & \multicolumn{1}{c|}{$\begin{array}{c}\text { Sum of } \\
\text { Squares }\end{array}$} & \multicolumn{1}{c|}{ Df } & $\begin{array}{c}\text { Mean } \\
\text { Square }\end{array}$ & F & Sig. \\
\hline \multirow{3}{*}{1} & Regression & 233.516 & 2 & 116.758 & 7.232 & .001 \\
\cline { 2 - 8 } & Residual & 1081.756 & 67 & 16.146 & & \\
\cline { 2 - 8 } & Total & 1315.271 & 69 & & & \\
\hline
\end{tabular}

Pendapatan merupakan imbalan yang Sumber: Data Diolah

Hasil uji F dalam tabel 9 dengan tingkat signifikansi $10 \%(0,1) . F_{\text {tabel }}$ diperoleh dengan cara df1 $=$ jumlah varibel $-1=(3-1=2)$ dan $\mathrm{df} 2=\mathrm{n}-\mathrm{k}-1=(70-2-1=67)$, maka diperoleh $F_{\text {tabel }}$ sebesar 2,38. Hasil uji $F$ diterima dari hasil melakukan sebuah pekerjaan. Pendapatan yang diterima dapat berasal dari berbagai sumber pendapatan yang dimiliki sangat berperan penting sebagai faktor dalam pemgabilan keputusan pembiayaan. Pendapatan yang tinggi akan mendorong pengambilan pembiayaan, dimana semakin tinggi pendapatan akan 
semakin memengaruhi keputusan melakukan pembiayaan.

Hasil penelitian ini sejalan dengan penelitian terdahulu. Penelitian terdahulu menunjukkan bahwa variabel pendapatan tidak berpengaruh positif signifikan terhadap keputusan pelanggan untuk menggunakan perbankan Islam.

Hasil penelitian ini menunjukkan pendapatan tidak menjadi salah satu pertimbangan bagi pedagang di Kecamatan Panyabungan dalam melakukan pembiayaan di bank syariah. Sehingga pedagang yang berpendapatan tinggi belum tentu akan melakukan pembiayaan di bank syariah.

2. Pengaruh Literasi Keuangan Syariah Terhadap Keputusan Melakukan Pembiayaan di Bank Syariah

Hasil uji t, menujukkan $t_{\text {hitung }}$ variabel literasi keuangan syariah sebesar 3,646 dengan sign. 0,001. Dengan ttabel sebesar 1,66792, maka variabel literasi keuangan syariah dengan $t_{\text {hitung }}>t_{\text {tabel }}(3,646>1,66792)$ dengan sign. 0,001<0,1. Hasil uji t literasi keuangan syariah menunjukkan hipotesis 2 diterima dan HO ditolak. Jadi disimpulkan bahwa literasi keuangan syariah berpengaruh terhadap keputusan pedagang melakukan pembiayaan di bank syariah di Kecamatan Panyabungan.

Literasi keuangan syariah berkaitan dengan kemampuan memahami produk dan layanan jasa keuangan berbasis syariah.
Literasi keuangan syariah yang baik, dapat memudahkan dalam memilih produk dan layanan jasa keuangan yang sesuai dengan kebutuhan yang diinginkan. Semakin tinggin tingkat literasi keuangan syariah, maka semakin memudahkan kepentingan dalam memilih pembiayaan.

Hasil penelitian ini sejalan dengan penelitian terdahulu. Penelitian terdahulu yang pertama menunjukkan bahwa literasi keuangan syariah berpengaruh positif dan signifikan terhadap keputusan masyarakat muslim menggunakan produk perbankan syariah di DIY baik secara parsial maupun simultan, dan penelitian terdahulu yang kedua menunjukkan pada uji t satu variabel berpengaruh signifikan yakni literasi keuangan syariah. Sehinnga penelitian terdahulu sejalan dengan penelitian ini.

Dengan demikian, literasi keuangan syariah menjadi faktor penentu bagi pedagang yang akan melakukan pembiayaan di bank syariah. Literasi keuangan syariah memuat tiga dimensi, yaitu pengetahuan keuangan, sikap keuangan dan perilaku keuangan, sehingga ketiga dimensi tersebut sangat berperan bagi pedagang yang akan melakukan pembiayaan di bank syariah sesuai dengan prinsip-prinsip syariah.

3. Pengaruh Pendapatan dan Literasi Keuangan Syariah Terhadap Keputusan Melakukan Pembiayaan di Bank Syariah.

Hasil uji $F$ yang telah dilakukan, diperoleh $F_{\text {hitung }}>F_{\text {tabel }}(7,232>2,38)$ dengan sign. $0,001<0,1$. Hasil uji $F$ menunjukkan 
hipotesis 3 diterima dan HO ditolak. Sehingga disimpulkan bahwa pendapatan dan literasi keuangan syariah secara simultan berpengaruh terhadap keputusan pedagang melakukan pembiayaan di bank syariah di Kecamatan Panyabungan.

Pendapatan menjadi salah satu faktor penting yang menjadi pertimbangan dalam mengambil pembiayaan. Begitu juga dengan literasi keuangan syariah, dimana literasi keuangan syariah itu menjadi kemampuan dasar dalam menentukan pembiayaan yang sesuai dengan kebutuhan.

Penelitian yang dilakukan oleh Prinando Berutu \& Susianto bahwa pendapatan berpengaruh dan signifikan terhadap keputusan nasabah, kemudian penelitian Rahmawati Deylla Handida \& Maimun Sholeh menunjukkan bahwa literasi keuangan syariah berpengaruh positif dan signifikan terhadap keputusan masyarakat muslim menggunakan produk perbankan syariah di Daerah Istimewa Yogyakarta baik secara parsial maupun simultan, kemudian penelitian Siti Homisyah Ruwaidah menunjukkan bahwa literasi keuangan syariah berpengaruh secara parsial dan simultan terhadap keputusan mahasiswa dalam menggunakan jasa perbankan syariah. Oleh karena itu, semakin tinggi pendapatan dan tingkat literasi keuangan syariah, maka akan memengaruhi keputusan melakukan pembiayaan.
POINT Vol. 2, No. 2, Des 2021

2. Saran

Semoga adanya pengetahuan masyarakat terhadap minat produk perbankan syariah

\section{DAFTAR PUSTAKA}

Ali Hardana, analisis Faktor-Faktor Yang Mempengaruhi Pendapatan Industri Kecil Di Kota Padangsidimpuan Dan Kabupaten Tapanuli Selatan Hardana Tazkir : Jurnal Penelitian Ilmu-ilmu Sosial dan Keislaman (iain-padangsidimpuan.ac.id)

Andrianto dan M. Anang Firmansyah. 2019. Manajemen Bank Syariah (Implementansi Teori dan Praktek). Surabaya: CV. Penerbit Qiara Media.

Anna Sardiana. 2016. "The Impact of Literacy to Shariah Financial Service Preferences." Etikonomi 15 (1).

Chaniago, Aspizain. 2017. Teknik Pengambilan Keputusan (Pendekatan Teori \& Studi Kasus). Jakarta: Lentera Ilmu Cendekia.

Copur, Zeynep. 2015. Handbook of Research on Behavioral Finance and Investment Strategies: Decision Making in the Financial Industry. United States of America: IGI Global.

Departemen Agama RI. 2011. Al-Qur'an dan Tafsirnya (Edisi yang Disempurnakan). Jakarta: Departemen Agama RI.

Febrida Khairani, Delima Sari Lubis \& Rodame Monitorir Napitupulu. 2020. "Determinan Pendapatan Rumah Tangga Muslim." Al-Masharif: Jurnal Ilmu Ekonomi dan Keislaman 8 (2).

Hoyer, Wayne D. and Deborah J. Maclnnis. 2010. Consumer Behavior, Fifth Edition. USA: South-Western Cengage Learning. 
Kementerian Keuangan Direktorrat Jenderal Perbendaharaan Kantor Wilayah Provinsi Sumatera Utara. 2020. Kajian Fiskal Regional Provinsi Sumatera Utara. Medan: Ditjen Perbendaharaan Provinsi Sumatera Utara.

Kotler, Philip, et. al.,. 2017. Marketing: an Introduction. Canada: Pearson Canada Inc.

Mohamad Azmi Abdullah \& Alex Anderson. 2015. "Islamic Financial Literacy Among Bankers in Kuala Lumpur." Journal of Emerging Economies and Islamic Research 3 (2).

Muhammad Taufiq El Ikhwan. 2019. "Determinan Literasi Keuangan Syariah." Al-Masharif: Jurnal IImu Ekonomi dan Keislaman 7 (1).

Noor, Juliansyah. 2011. Metodologi Penelitian: Skripsi, Tesis, Disertasi, dan Karya Ilmiah. Jakarta: Kencana.

Nutt, Paul C. And David C. Wilson, Ed. 2010. Handbook of Decision Making. United Kingdom: John Wiley \& Sons Ltd.

Piros, Christopher D. \& Jerald E. Pinto. 2013. Economics For Investment Decision Makers: Micro, Macro, And International Economics. Hoboken, New Jersey: John Wiley \& Sons.

Potrich, Ani Caroline Grigion, Kelmara Mendes Vieira \& Wesley Mendes-Da-Silva. 2016.
"Development of a financial literacy model for university students." Management Research Review 39 (3).

Priyono \& Teddy Chandra. 2016. Esensi Ekonomi Makro. Sidoarjo: Zifatama Publisher.

Rike Setiawati, Sulaeman Rahman Nidar, Mokhamad Anwar, \& Dian Masyita. 2018. "Islamic Financial Literacy: Construct Process and Validity." Academy of Strategic Management Journal 17 (4).

Shinta, Agustina. 2011. Manajemen Pemasaran. Malang: Universitas Brawijaya Press (UB Press).

Siregar, Syofian. 2012. Statistika Deskriptif untuk Penelitian: Dilengkapi Perhitungan Manual dan Aplikasi SPSS Versi 17. Jakarta: Rajawali Press.

Siti Homisyah Ruwaidah. 2020. "Pengaruh Literasi Keuangan Syariah dan Shariah Governance Terhadap Keputusan Mahasiswa dalam Menggunakan Jasa Perbankan Syariah." Muhasabatuna: Jurnal Akuntansi dan Keuangan Islam 1 (1).

Sugiyono. 2016. Metode Penelitian Kuantitatif, Kualitatif, dan R\&D. Bandung: Alfabeta.

Widayat. 2010. "Penentu Perilaku Berinvestasi." Ekonomika-Bisnis 1 (2). 